UDC $007: 304: 070+001+004.9$

\title{
Social and Communication Technologies of Propagandism of the Links among Europe, Germany and Ukraine in Press of the Reichcommissariat "Ukraine" (in the period from 1 September 1941 to 17 July 1942)
}

\author{
Alexander Kholod \\ Kyiv National University of Culture and Arts, 36 Konovaltsia str., Kyiv, 01133, Ukraine \\ Corresponding author's e-mail address: akholod@ukr.net
}

\begin{abstract}
Three aspects of the problem are studied in this research. The first aspect is the lack of knowledge about a range of European-Ukrainian and German-Ukrainian relations covered by the press controlled by the Reichcommissariat "Ukraine" (hereinafter - RCU) in the period from its foundation up to the beginning of the Battle of Stalingrad. The second aspect is the lack of studies on the identification and description of the specific social and communication technologies of influence through the RCU press on the minds of readers. The third aspect is the inaccuracies detected in previous studies by Ukrainian researchers, in descriptions of methods used in newspapers published under the RCU censorship. To fill these gaps in knowledge, the author has chosen as an object of study the press (newspapers) of the Reichcommissariat "Ukraine" from 1 September 1941 to 17 July 1942. The subject of the study is the range and trends in the Ukrainian-European and Ukrainian-German relations covered by the RCU press in the given period.

In the study, the author identified the range and trends in covering the Ukrainian-European and Ukrainian-German relations in the press of the Reichcommissariat "Ukraine" in the period from 1 September 1941 to 17 July 1942. The main results of the study are the differentiations of journalistic materials in the specified period by two criteria. By the first criterion, we identified a range of topics in journalistic materials, both in quantity and quality, in the following two groups: "Ukrainian-European relations" and " Ukrainian-German relations." By the second criterion of the analysis (the quantity and quality of the main trends of Ukrainian-European and Ukrainian-German relations covered by the RCU press from the first day of its foundation, 1 September 1941, to the first day of the Battle of Stalingrad, 17 July 1942) four main trends were outlined, namely: 1) insisting of the RCU press on rightness of Germany's war against the Bolshevism; 2) imposing of the idea of necessity to work aiming at assisting the German soldiers; 3 ) promotion of the idea of precedence of German culture as a model for the Ukrainians; 4) propagandism of the advantages of the new, German order in Ukraine. The study confirmed the author's hypothesis that in the period prior to the Battle of Stalingrad, the RCU newspapers employed the social and communication technologies of propaganda to more intensively promote the Ukrainian-German relations than the Ukrainian-European relations.
\end{abstract}

KEYWORDS: social and communication technologies, propaganda, media in Reichcommissariat "Ukraine", Ukrainian-German relations, Ukrainian-European relations. 
УДК $007: 304: 070+001+004.9$

\section{Соціальнокомунікаційні технології пропаганди зв'язків Свропи, Німеччини й України в пресі Рейхскомісаріату "Україна" (у період від 1 вересня 1941 р. до 17 липня 1942 р.)}

Холод Олександр Михайлович, Київський наџіональний університет культури і мистецтвв, професор, доктор філологічних наук

Резюме

Метою дослідження було виокремлення діапазону, його опис та визначення тенденцій європейсько-українських та німецько-українських зв'язків, декларованих пресою Рейхскомісаріату «Україна» (далі - РКУ) в період від 1 вересня 1941 р. до 17 липня 1942 р.

Основними результатами стала диференціація журналістських матеріалів вказаного періоду за двома критеріями. Згідно з першим критерієм, ми визначили діапазон тем журналістських матеріалів за кількістю та якістю у двох таких групах: «українсько-європейські зв'язки» та «німецько-українські зв'язки». За другим критерієм аналізу (кількість та якість основних тенденцій європейсько-українських та німецько-українських зв'язків, декларованих РКУ від першого дня його заснування, 1 вересня 1941 р., до першого дня Сталінградської битви, 17 липня 1942 р.) виокремлено чотири основні тенденції: 1) наполягання на думці про правильність війни Німеччини проти більшовизму; 2) нав'язування думки про необхідність працею допомагати німецькому солдатові; 3) просування ідеї пріоритетності німецької культури як зразкової для українців; 4) пропагування переваг нового німецького порядку в Україні. Дослідження підтвердило гіпотезу автора, що преса (газети) РКУ до Сталінградської битви активніше використовували соціальнокомунікаційні технології пропаганди українсько-німецьких зв'язків, ніж українсько-європейських.

Ключові слова: соціальнокомунікаційні технології, пропаганда, преса Рейхскомісаріату «Україна», українсько-німецькі відносини, українсько-європейські відносини.

Холод А.М. Социальнокоммуникационные технологии пропаганды связей Европы, Германии и Украины в прессе Рейхскомиссариата «Украина» (в период от 1 сентября 1941 г. по 17 июля 1942 г.).

Резюме. Целью исследования было выделение диапазона, его описание и определение тенденций европейско-украинских и немецко-украинских связей, декларируемых прессой Рейхскомиссариата «Украина» (далее - РКУ) в период с 1 сентября 1941 г. по 17 июля 1942 г.

Основными результатами стала дифференциация журналистских материалов указанного периода по двум критериям. Согласно первому критерию, мы определили диапазон тем журналистских материалов по количеству и качеству в двух таких группах: «украинско-европейские связи» и «немецко-украинские связи». По второму критерию анализа (количество и качество основных тенденций европейско-украинских и немецко-украинских связей, декларируемых прессой РКУ с первого дня его основания, 1 сентября 1941 г., и до первого дня Сталинградской битвы, 17 июля 1942 г.) мы выделили четыре основные тенденции: 1) настаивает на мнении о правильности войны Германии против большевизма; 2) навязывание мысли о необходимости трудом помогать немецкому солдату; 3) продвижение идеи приоритетности немецкой культуры как образцовой для украинцев; 4) пропаганда преимуществ нового немецкого порядка в Украи- 
не. Исследование подтвердило гипотезу автора, что пресса (газеты) РКУ до Сталинградской битвы активнее использовали социальнокоммуникационные технологии пропаганды украинско-немецких связей, чем украинско-европейских.

Ключевые слова: социальнокоммуникационные технологии, пропаганда, пресса Рейхскомиссариата «Украина», украинско-немецкие отношения, украинско-европейские отношения.

\section{1. Вступ}

Проблема, яку ми розглядаємо, містить декілька прошарків і базується на відсутності інформації про те, завдяки якими комунікаційним прийомам (засобам, технологіям і технікам) у пресі керівництво Рейхскомісаріату «Україна» (далі - РКУ) здійснювало пропаганду, спрямовану на карбування у свідомості населення окупованої України (колишньої Української Радянської Соціалістичної Республіки) у період першого року від дня заснування РКУ [1] ідеї європейсько-українських та німецько-українських зв’язків.

Першим прошарком декларованої нами проблеми є відсутність знань про діапазон європейсько-українських та німецько-українських зв'язків, декларованих пресою, що була підконтрольною РКУ в період від його заснування до початку Сталінградської битви.

Другим прошарком аналізованої нами проблеми вважаємо відсутність досліджень, присвячених виявленню та опису конкретних соціально-комунікаційних технологій впливу через пресу РКУ на свідомість читачів.

Третім прошарком проблеми є неточність деталей в описах прийомів журналістських матеріалів газет, які виходили під цензурою РКУ, що свого часу наштовхнуло дослідників на неточні висновки. Наприклад, дослідник Б. Черняков стверджував, що «1 вересня до Рейхскомісаріату Україна передані райони Кам'янця-Подільського і південні частини Брестської і Поліської областей Білорусі» [2]. У документах РКУ [1; 3-5], зазначено, що від 1 вересня 1941 року «в адміністративному відношенні райхскомісаріат поділявся на шість генеральних округ (нім. Generalbezirke): Волинь і Поділля, Житомир, Київ, Дніпропетровськ, Миколаїв і Таврія» [6]. Отже, райони Кам'янця-Подільського й південні частини Брестської і Поліської областей Білорусі не могли на той час входити до складу РКУ.

Окрім того, Б. Черняков стверджує, що «окупанти викорінювали вказівку на національну ознаку й оцінні характеристики патріотичного спрямування. Їх влаштовували лише топонімічні означення, які не нагадували читачам про належність до українства, а позначали місце видання лише територіально» [2; 7]. Вважаємо твердження Б. Чернякова некоректним, оскільки з 34 (100\%) видань (газет), що виходили від 1 вересня 1941 року до 17 липня 1942 року за фінансової підтримки й цензури з боку РКУ, ми нарахували 13 (38\%) таких, у назві яких було слово 3 кореневою морфемою «україн-». Ще 14 (41\%) видань мали назву, у якій чітко прослідковувалася географічна віднесеність до міст України (наприклад, «Голос Волині» (місто видання - Житомир); «Дніпропетровська газета» (місто видання - Дніпропетровськ); «Васильківські вісті» (м. Васильків Київської області); «Волинь. Український часопис» (м. Рівне); «Голос Волині» (м. Житомир); «Голос Сарненщини» (м. Сарни Рівненської області); «Звягельське слово» (м. Звягель, нині - м. НовоградВолинський Житомирської області); «Іванківські вісті» (м. Іванків Київської області); «Ковельські вісті» (м. Ковель Волинської області); «Козятинська газета» (м. Козятин Волинської області); «Костопільські вісті» (м. Костопіль Рівненської області); «Переяславські вісті» (м. Переяслав Київської області); «Ружинський вісник» (м. Ружин Житомирської області). Отже, 13 (38\%) видань, у назві яких була присутня коренева морфема «україн-», та 14 (41\%) видань, назва яких відбивала назву населеного пункту чи географічної місцини, склали в сумі 27 (79\%), що спростовує твердження Б. Чернякова про «викорінення 
вказівок на національну ознаку й оцінні характеристики патріотичного спрямування» [2].

Окрім Б. Чернякова, проблеми окупаційної та фашистської преси досліджували В. Владимиров [8], I. Мальчевський [9], І. Стафийчук [10], I. Чайковський [11-12].

Не торкаючись третього й другого прошарків означеної нами проблеми, зупиняємося на першому іiї прошарку, а саме відсутності знань про діапазон і тенденції європейськоукраїнських та німецько-українських зв'язків, декларованих пресою, що була підконтрольною РКУ в період від його заснування до початку Сталінградської битви.

Об’єктом дослідження обрали пресу (газети) Рейхскомісаріату «Україна» (від 1 вересня 1941 року до 17 липня 1942 року), предметом - діапазон та тенденції європейськоукраїнських та німецько-українських зв'язків, декларованих пресою Рейхскомісаріату «Україна» у згаданий період.

Метою дослідження визначили виокремлення діапазону, його опис та визначення тенденцій європейсько-українських та німецько-українських зв'язків, декларованих пресою Рейхскомісаріату «Україна» (у період від 1 вересня 1941 до 17 липня 1942 року).

\section{2. Методи дослідження}

Для досягнення мети звернулися до таких груп методів наукового пізнання за першою класифікаиією:

1) загальні (діалектичний метод);

2) загальнонаукові методи (аналіз, синтез, абстрагування, узагальнення, аналогія та класифікація);

3) спеціальні (фахові, або галузеві) наукові методи (контент-аналіз).

За другою класифікаиією залучили такі методи дослідження:

1) методи теоретичного дослідження (статистичні методи);

2) методи емпіричного дослідження (спостереження, опис та вимірювання).

Методика вивчення передбачала такі дослідницькі процедури:

1) здійснення аналізу джерел, що свідчать про адміністративно-господарський устрій Рейхскомісаріату «Україна» у період від 1 вересня 1941 року до 17 липня 1942 року;

2) установлення конкретного переліку й назв газетних видань (із вказуванням міст їхнього видання);

3) здійснення контент-аналізу журналістських матеріалів профашистських авторів для виокремлення, опису та класифікації європейсько-українських та німецькоукраїнських зв'язків, декларованих пресою Рейхскомісаріату «Україна» (у період від 1 вересня 1941 до 17 липня 1942 року) ;

4) опис та класифікація основних тенденцій європейсько-українських та німецькоукраїнських зв'язків, декларованих пресою Рейхскомісаріату «Україна» у період від 1 вересня 1941 року до 17 липня 1942 року.

\section{3. Результати й обговорення}

Виконуючи першу процедуру дослідження (аналіз джерел, що свідчать про адміністративно-господарський устрій Рейхскомісаріату «Україна» у період від 1 вересня 1941 року до 17 липня 1942 року), ми встановили, що, за даними попередніх досліджень [6; 8-10; 1315], на території Рейхскомісаріату «Україна» (частина окупованої території УРСР) від 1 вересня 1941 року до 17 липня 1942 року діяли 6 генеральних округів, а саме: Волинь/Поділля (центр у м. Рівне); Житомир, Київ, Миколаїв, Дніпропетровськ та частина Тавріі/Криму (центр у м. Мелітополь).

Друга процедура дослідження передбачала встановлення конкретного переліку й назв газетних видань (із вказуванням міст їхнього видання). 
У зазначений період на території згаданих шести округів видавалися за гроші окупантів 34 газети (10 газет видавалися 1941 року й 24 газети - 1942 року).

1941 року видавалися 10 газет:

1) «Голос Волині» (місто видання - Житомир);

2) «Дзвін» (місто видання - Біла Церква);

3) «Дзвін» (місто видання - Кривий Ріг);

4) «Дніпропетровська газета» (місто видання - Дніпропетровськ);

5) «Звільнена Україна» (м. Богуслав Дніпропетровської області);

6) «Нове українське слово» (м. Київ);

7) «Останні вісті» (м. Київ);

8) «Українська думка» (м. Миколаїв);

9) «Українське життя» (м. Бориспіль Київської області);

10) «Українське слово» (м. Житомир);

1942 року видавалися 24 газети:

1) «Васильківські вісті» (м. Васильків Київської області);

2) «Відродження» (м. Тараща Київської області);

3) «Вісті» (м. Рівне);

4) «Волинь. Український часопис» (м. Рівне);

5) «Голос Волині» (м. Житомир);

6) «Голос Сарненщини» (м. Сарни Рівненської області);

7) «Дніпропетровська газета» (м. Дніпропетровськ);

8) «Звягельське слово» (м. Звягель, нині - м. Новоград-Волинський Житомирської області);

9) «Іванківські вісті» (м. Іванків Київської області);

10) «Ковельські вісті» (м. Ковель Волинської області);

11) «Козятинська газета» (м. Козятин Волинської області);

12) «Костопільські вісті» (м. Костопіль Рівненської області);

13) «Наше слово» (м. Береста Рівненської області);

14) «Наші вісті» (м. Любомль Волинської області);

15) «Нове українське слово» (м. Київ);

16) «Переяславські вісті» (м. Переяслав Київської області);

17) «Последние новости» (м. Київ);

18) «Ружинський вісник» (м. Ружин Житомирської області);

19) «Українець» (м. Павлоград Дніпропетровської області);

20) «Українська думка» (м. Миколаїв);

21) «Українське життя» (м. Бориспіль Київської області);

22) «Український голос» (м. Луцьк);

23) «Український хлібороб» (м. Київ);

24) «Український хлібороб» (м. Рівне).

За третьою дослідницькою процедурою ми здійснили контент-аналіз (за одиницями «слово» і «тема») журналістських матеріалів профашистських авторів для виокремлення, опису та класифікації європейсько-українських та німецько-українських зв'язків, декларованих пресою Рейхскомісаріату «Україна» (у період від 1 вересня 1941 до 17 липня 1942 року).

У дослідницьку вибірку увійшли 1240 (100\%) журналістських матеріалів (фото, карикатури, статті, фельєтони, інформаційні замітки, розширені інформаційні замітки, аналітичні статті, оголошення, інтерв’ю, замальовки, портрети, повідомлення, звіти, хроніки тощо). Аналізу підлягали назви журналістських матеріалів.

Контент-аналіз, здійснений за одиницею «слово», дозволив нам у назвах журналістсь- 
ких матеріалів зафіксувати 12 (0,9\% від загального числа вибірки в 1240 журналістських матеріалів) випадків вживання слів із коренем «європ-» (наприклад, «Е(Є)вропа», «європейці», «європейський»); із коренем «захід-» (наприклад, «західний», «Захід»).

Ілюстраціями назв журналістських матеріалів, у яких вживаються слова 3 кореневою морфемою «європ-» та «захід-», є такі:

1) «Україна - бастіон Свропи» («Український голос» від 11.06.1942. - с. 2);

2) «Всі українці мусять прилучатися до фронту збудженої зі сну Європи» («Вісті для українських селян» від 08.07.1942. - c.1);

3) «В новій Європі» («Останні вісті» від 17.11.1941. - с. 2);

4) «Сталін готував війну проти Свропи» («Останні вісті» від 24.11.1941. - с. 1);

5) «Перемога Німеччини - визволення Свропи» («Українське життя» від 21.10.1941. - с. 1);

6) «Турецьке визнання нового ладу Свропи» («Голос Волині» від 23.10.1941. - с. 2);

7) «Продуктивні сили Свропи» («Голос Волині» від 30.11.1941. - с. 1);

8) «Нова Україна - охоронний вал Свропи перед небезпекою зі Сходу!» («Голос Волині» від 30.11.1941. - с. 2);

9) «Україна - посередник Західної культури» («Голос Волині» від 07.12.1941. - с. 3);

10) «Перемоги для Свропи» («Голос Волині» від 11.12.1941. - с. 1);

11) «Західні великодержави і проблема Сходу Свропи» («Голос Волині» від 03.01.1942. - c. 2);

12) «Свропа і ми» («Волинь. Часопис для Волині» від 07.09.41. - с. 1) та таке інше.

Під час здійснення контент-аналізу назв журналістських текстів та сюжетів світлин як журналістських матеріалів за одиницею «тема» з'явилася можливість зафіксувати тему європейсько-українських та німецько-українських зв'язків у 17-ти випадках. Ілюстраціями журналістських матеріалів за темою «українсько-європейські та німецько-українських зв'язки» $є$ такі назви і фрагменти текстів:

1) назва рубрики «3 господарського життя у Німеччині» («Голос Волині» від 14.12.1941. - с. 3):

2) «Як допомагають у Німеччині родинам»;

3) «Водний шлях від Північного до Чорного морів» (про шлях до морів через Великонімеччину);

4) «Річкове пароплавство» (про пароплавство в Німеччині);

5) «Державні автостради» (про автостради в Німеччині);

6) «Розвиток німецького коневодства» (про коневодство у Німеччині) (назви у п.п. 2-6 зафіксовано в газеті «Голос Волині» від 14.12.1941. - с. 3);

7) «Як організована німецька молодь» («Голос Волині» від 17.12.1941. - с. 2);

8) «Охорона здоров'я в Німеччині»;

9) «Організація німецького народного господарства»;

10) «Театр нової доби» (про діяльність театрів у Німеччині);

11) «Закордонні робітники в Німеччині» (назви повідомлень, зазначених у п.п. 8)-11), зафіксовано в газеті «Голос Волині» від 17.12.1941. - с. 3);

12) «Молоде, де ти?» (автор «Б-кий В.»; надруковано в газеті «Українська думка» від 22.11.1941. - с. 3; у тексті критикуються негативи більшовицького виховання й говориться про завдання у вихованні європейської молоді; про необхідність здобуття молоддю європейської освіти);

13) «Чому Німеччина мусіла вести війну на Сході?» («За генералом фон Тішовіц»; матеріал надруковано в газеті «Українська думка» від 03.12.1941. - с. 1; у матеріалі йдеться про загрозу більшовизму всій Європі; про анексію більшовиками в 1939 році Литви, Латвії, Естонії; про прагнення більшовиків зробити військові бази в Болгарії, у Дарданелах та 
Фінляндії: про те, що Німеччина врятувала Європу від наступу більшовиків);

14) «Плани Німеччини» (у матеріалі йдеться про необхідність українському народові сприймати й засвоювати всі здобутки європейсько-німецької культури; про «щасливе майбутнє нашого народу в сім'ї передових народів Свропи, керованою Німецькою державою» («Нове Українське Слово» від 16.12.1941. - с. 1);

15) «Німці не прийшли в Україну з порожніми руками» («...серед численних поїздів, що котяться в Україну...»; «Тисячі штук ріжнородних розплодових домашніх тварин привезено з Німеччини в Україну»; «Цей розплодовий матеріал відновить знищену більшовиками українську годівлю худоби»; «Гідним подиву $є$ не тільки дійсність самого постачання, але теж і якість ввоженого матеріалу, який німці в часі війни, не дивлячись на високі власні господарські вимоги, доставляють ще й для відбудови українського господарства. Українське селянство, дивлячись перший раз на такі величезні транспорти матеріалів, не могло вийти з дива. Йому ясно, де гледіти за причинами великих німецьких воєнних успіхів, тому воно висловлювалось: народ, що майже по трирічним веденні війни виробляє ще сьогодні такі високоякісні машини і їх постачає поза свої границі для невоєнних цілей, мусить перемогти» («Вісті для українських селян» від 08.07.1942. - с. 1);

16) «Селяни!» (автор - «Районшеф (...) Франц Рутковський»; у матеріалі подається заклик про те, що «непереможна німецька армія щораз далі жене на схід совєтські орди»; автор матеріалу наказує: «Тому пам'ятайте, що земля, звернена вам німецькою владою у власність, залишиться у вашому та вашого потомства посіданні назавжди. Колгоспиголодомори ваших родин уже ніколи не повернуться»; Франц Рутковський пише: «Відчинені та відбудовані по літах неволі церкви будуть завжди заспокоювати ваші релігійні потреби та морально лікувати тяжкі рани пережитого лиха»; щодо основ культурного розвитку дописувач повідомляє про те, що «шкільництво в рідній українській мові допроводить вас до осягнення культури братнього німецького народу, який, завдяки своїй високій культурі, став великою потугою світа» («Наше слово» від 05.07.1942. - с. 4);

17) «Рейхсміністр Розенберг про становище й завдання України» (у матеріалі йдеться про наміри німецького командування принести мир українцям від більшовиків-жидів і внести високу німецьку європейську культуру в життя українців («Наше слово» від 05.07.1942. - c. 2).

Ілюстраціями журналістських матеріалів за темою «українсько-європейські» та «українсько-німецькі зв'язки» є такі світлини:

1) «Як Німеччина вшановувала пам'ять великого німецького композитора Моцарта» (зображення натовпу людей, які стоять біля пам'ятника В.А. Моцарту);

2) «Чудова гірська околиця в Німеччині» (зображено гірський краєвид із декількома будинками біля підніжжя гори) (світлини, назви яких подано в п.п. 1) та 2), надруковані в газеті «Голос Волині» від 03.01.1942. - с. 3);

3) «Так живе робітник у Рейху. Ідеал і його здійснення» (на світлині зображено чисту кімнату, у якій у широке і світле вікно дивляться мати й немовля у неї на руках; світлину подано в газеті «Наші вісті» від 13.09.1942. - с. 4);

4) «Чудова Німеччина» - фоторубрика: на світлині зображено «прекрасно положений монастир бенедиктинців в Мельку...» (газета «Наші вісті» від 28.06.1942. - с. 3);

$5)$ «Берлінський зоологічний сад» (світлина зафіксувала зоосад у м. Берлін із чистими стежинами між клітками 3 тваринами, біля яких стоять люди і дивляться на тварин («Наше слово» від 18.06.1942. - с. 4);

6) «В таких хатах живуть тепер німецькі селяни» (на світлині зображено чисту вулицю 3 двоповерховими будинками та садибами біля них у селі біля м. Франкфурт, що в Німеччині; газета «Волинь. Часопис для Волині» від 23.11.1941. - с. 3);

7) «Так виглядають німецькі дороги» (фотографія містить зображення німецької ав- 
тостради $з$ покриттям, на якому не видно жодної ями чи пошкодження; газета «Волинь. Часопис для Волині» від 19.10.1941. - с. 3);

8) «Німецька молодь відбуває...» (на світлині можна побачити зображення групи щасливих молодих людей, які перебувають на відпочинку в спортивному таборі для молоді; зображення подано на фоні красивого триповерхового будинку, перед яким - спортивний майданчик для гри у волейбол; світлина подана в газеті «Наші вісті» від 31.05.1942. c. 4);

9) «У Загребі в кінці осені...» (фотографія містить зображення мальовничої вулиці в курортному м. Загреб; світлина надрукована в газеті «Ковельські вісті» від 05.04.1942. с.5) та інші.

Четверта дослідницька проиедура передбачала опис та класифікацію основних тенденцій європейсько-українських та німецько-українських зв'язків, декларованих пресою Рейхскомісаріату «Україна» у період від 1 вересня 1941 року до 17 липня 1942 року. Згадана процедура передбачала виокремлення певних критеріїв визначення згаданих тенденцій та їхньої подальшої класифікації. До таких критеріїв ми віднесли:

1) кількість та якість тем журналістських матеріалів, що висвітлювали європейськоукраїнські та німецько-українські зв'язки в пресі, підконтрольній Рейхскомісаріату «Україна» у період від 1 вересня 1941 року до 17 липня 1942 року;

2) кількість і якість основних тенденцій європейсько-українських та німецькоукраїнських зв'язків, декларованих РКУ в згаданий період.

\section{4. Висновки}

Згідно з першим критерієм, ми визначили діапазон тем журналістських матеріалів за кількістю та якістю у двох таких групах:

Перша група - «Українсько-європейські зв'язки»

1) Україна - бастіон Свропи;

2) українці повинні прилучатися до фронту;

3) оновлена Європа;

4) завоювання Сталіним Свропи;

5) перемога Німеччини як визволителя Свропи;

6) новий лад Свропи;

7) продуктивні сили Європи;

8) Україна - посередник Західної культури;

9) проблема Сходу Європи;

10) Європа і ми.

Друга група - «Німецько-українські зв'язки»

1) господарське життя Німеччини;

2) соціальний захист громадян Німеччини;

3) висока якість державних автошляхів Німеччини;

4) водні шляхи Великонімеччини;

5) розвиток німецького коневодства;

6) організація німецької молоді;

7) охорона здоров'я в Німеччині;

8) театри Німеччини;

9) закордонні робітники в Німеччині;

10) Німеччина - визволитель від більшовизму;

11) німці допомагають українцям у відновленні господарства, зруйнованого більшовиками; 
12) Німеччина - зразок високої культури для українців;

13) завдання для звільненої України;

14) Німеччина - чудова країна.

Другий критерій аналізу (кількість та якість основних тенденцій європейськоукраїнських та німецько-українських зв'язків, декларованих Райхскомісаріатом «Україна» від першого дня його заснування, 1 вересня 1941 року, до першого дня Сталінградської битви, 17 липня 1942 року) дозволив нам виокремити такі основні тенденції європейськоукраїнських та німецько-українських зв'язків, декларованих пресою Рейхскомісаріату «Україна» у згаданий період:

1) наполягання на думці про правильність дій Німеччини у веденні війни проти світового більшовизму;

2) нав'язування думки українському населенню СРСР про необхідність працею допомагати німецькому солдатові;

3) просування ідеї пріоритетності німецької культури як зразкової європейської культури для українців;

4) пропагування переваг нового німецького порядку в Україні.

У подальших дослідженнях європейсько-українських та німецько-українських зв'язків, декларованих пресою Рейхскомісаріату «Україна», слід звернути особливу увагу на маніпуляційні технології, що використовувалися авторами журналістських матеріалів для «вмонтування» у свідомість українців ідей, потрібних керівництву Третього Рейху.

\section{Подяки}

Висловлюємо подяку кандидату філологічних наук, доценту Ганні Ярославівні Холод за клопітку роботу щодо стилізації тексту статті, та працівникам читальної зали газетного відділу Національної бібліотеки України імені М.I. Вернадського за терпіння й уважність до нашого дослідницького запиту.

\section{References}

1. Hornauer, H. (1944), Zwei Jahre Aufbau und Entwscklung des Verlag und Druckereiwesens im Reichscommissariat Ukraine 1941-1943, Dresden, 68 p.

2. Chernyakov, B.I. (2005), "Periodical press in the occupied territory of Ukraine", Scientific Proceedings of the Institute of Journalism [Naukovi Zapysky Instytutu Zhurnalistyky], vol. 18, pp.131-158.

3. State Archive of Rivne Region in Ukraine (2015), "Die Presse im Reichskornmissariat Ukraine", F. R-22, op. 1. Spr. 149. Ark. 21-27.

4. "Liste der 17 ukrainischen und russischen Zeitungen, die von der Propaganda - Abteilung Ukraine an den Reichskommissar Ukraine Uber goben warden" (1998), in Kosyk, V.M., Ukraine in World War II, Documents: Collection of German Archival Documents, Lviv, vol. 2, pp. $247-$ 248 (in German), 240-241 (in Ukrainian).

5. Territoriale Veränderungen in Deutschland und deutsch verwalteten Gebieten 1874-1945 (2013), available at: http://www.territorial.de/index.htm (accessed 4.06.2015).

6. Wikipedia (2015), "Reichskommissariat Ukraine", available at: http://uk.wikipedia.org/wiki/Рейхскомісаріат_Україна (accessed 4.06.2015).

7. Chernyakov, B.I. (2003), "Occupation Press in Reichskommissariat Ukraine”, Proceedings of the Research Center of Periodicals at V.Stefanyk Lviv National Library [Zb. prats Naukovo-doslidnoho tsentru periodyky Lvivskoyi natsionalnoyi biblioteky imeni V. Stefanyka], Lviv, pp. 152-159. 
8. Vladymyrov, V.M. (2011), "Press the Third Reich: through self-destruction", World of Social Communications [Svit sotsialnykh komunikatsiy], KyMU, DonNU, Kyiv, pp. 102-106.

9. Malchevskyy, I. (1985), "Ukrainian newspapers under German occupation", in In Call of Kyiv: Ukrainian Nationalism in World War II: Collection of Articles, Memoirs and Documents, Novyy Shlyakh, Toronto-New York, pp. 291-295.

10. Stafyychuk, Y.P. (1968), Komsomol of Ukraine in Guerrilla Movement in 1941-1944 (Political Work among the Population of the Occupied Areas), Mysl, Moscow, pp. 26.

11. Chaykovskyy, I. (1966), "Ukrainian periodicals at the time of German occupation, 19411944", Echo of Ukraine - Literature and Art [Homin Ukrainy - Literatura i mystetstvo], no. 7.

12. Chaykovskyy, I. (1976), Ukrainian periodicals in the Second World War, 1939-1945, Kyiv, Filadelfiya, 19 p.

13. "Hitler's order to transfer all power in the occupied territory of the commander of the Wehrmacht" (1963), in Criminal Goals - Criminal Means [Prestupnble tsely - prestupnble sredstva], Moscow, pp.47-48.

14. Central State Archive of Public Organizations of Ukraine (2015), "Two years of development of the publishing and printing in Reichskommissariat Ukraine. 1941-1943", F. 166, op. 3. Od.zb. 146, 44 p.

15. Books and Textbooks on the History of Ukraine and World History (2015), "Hitler's decree on the establishment of the Reichscommisariat Ukraine, available at: http://www.history.vn.ua/book/xrestomatia/635.html (accessed 4.06.2015).

\section{Список джерел}

1. Zwei Jahre Aufbau und Entwscklung des Verlag und Druckereiwesens im Reichscommissariat Ukraine 1941-1943 / Hans Hornauer. Dresden, am 25. Januar 1944. - 68 S.

2. Черняков Б.І. Періодична преса на окупованій території України / Б.І. Черняков // Наукові записки Інституту журналістики. - 2005. - Т.18. - С.131-158.

3. Die Presse im Reichskornmissariat Ukraine // Держ. архів Рівненської обл. - Ф. Р-22, оп. 1. - Спр. 149. - Арк. 21-27.

4. Liste der 17 ukrainischen und russischen Zeitungen, die von der Propaganda - Abteilung Ukraine an den Reichskommissar Ukraine Uber goben werden // Косик В.М. Україна в Другій світовій війні у документах: 3б. німецьких архівних матеріалів. - Л., 1998. - Т. 2. - С. 240241, 247-248.

5. Territoriale Veränderungen in Deutschland und deutsch verwalteten Gebieten 1874-1945 [Електронний ресурс]. - Режим доступу: http:/www.territorial.de/index.htm. - Назва з екрану. - Дата доступу: 4.06.2015.

6. Рейхскомісаріат Україна // Вікіпедія [Електронний ресурс]. - Режим доступу: http://uk.wikipedia.org/wiki/Рейхскомісаріат_Україна. - Назва 3 екрану. - Дата доступу: 4.06.2015.

7. Черняков Б.І. Окупаційна преса Рейхскомісаріату Україна / Б.І. Черняков // 3б. праць Науково-дослідного центру періодики ЛНБ ім. В.Стефаника. - Л., 2003. - С. 152-159.

8. Владимиров В.М. Преса третього рейху: шляхом самознищення / В.М. Владимиров // Світ соціальних комунікацій [гол. ред. О.М. Холод]. - К.: КиМУ, ДонНУ, 2011. - С. 102 106.

9. Мальчевський І. Українська преса під німецькою окупацією / І. Мальчевський // На зов Києва: Український націоналізм у ІІ світовій війні: зб. статей, спогадів і документів. Торонто; Нью-Йорк: Новий шлях, 1985. - С. 291-295.

10. Стафийчук И.П. Комсомол Украины в партизанском движении 1941-1944 гг.: (Политработа среди населения оккупированных районов). - М.: Мысль, 1968. - С. 26.

11. Чайковський І. Українські періодичні видання за німецької окупації, 1941-1944 // 
Гомін України - Література і мистецтво. - 1966. - Ч.7. - 16 лип.

12. Чайковський I. Українські періодичні видання в Другій світовій війні, 1939-1945 / Ред. і доп. М. Кравчук. - Філадельфія: Київ, 1976. - 19 с.

13. Приказ Гитлера о передаче всей полноты власти на оккупированной территории командующим войсками вермахта // Преступные цели - преступные средства. - М., 1963. - C. $47-48$.

14. Два года устройства и развития издательского и печатного дела в Рейхскомиссариате Украины. 1941-1943: [Отчет] / Ганс Горнауэр // ЦДАГО України. - Ф. 166, оп. 3. Од. зб. 146. - 44 арк.

15. Декрет Гітлера про створення Рейхскомісаріату Україна (20 серпня 1941 р.) [Електронний ресурс]. - Режим доступу: http://www.history.vn.ua/book/xrestomatia/635.html. Назва з екрану. - Дата доступу: 4.06.2015. 